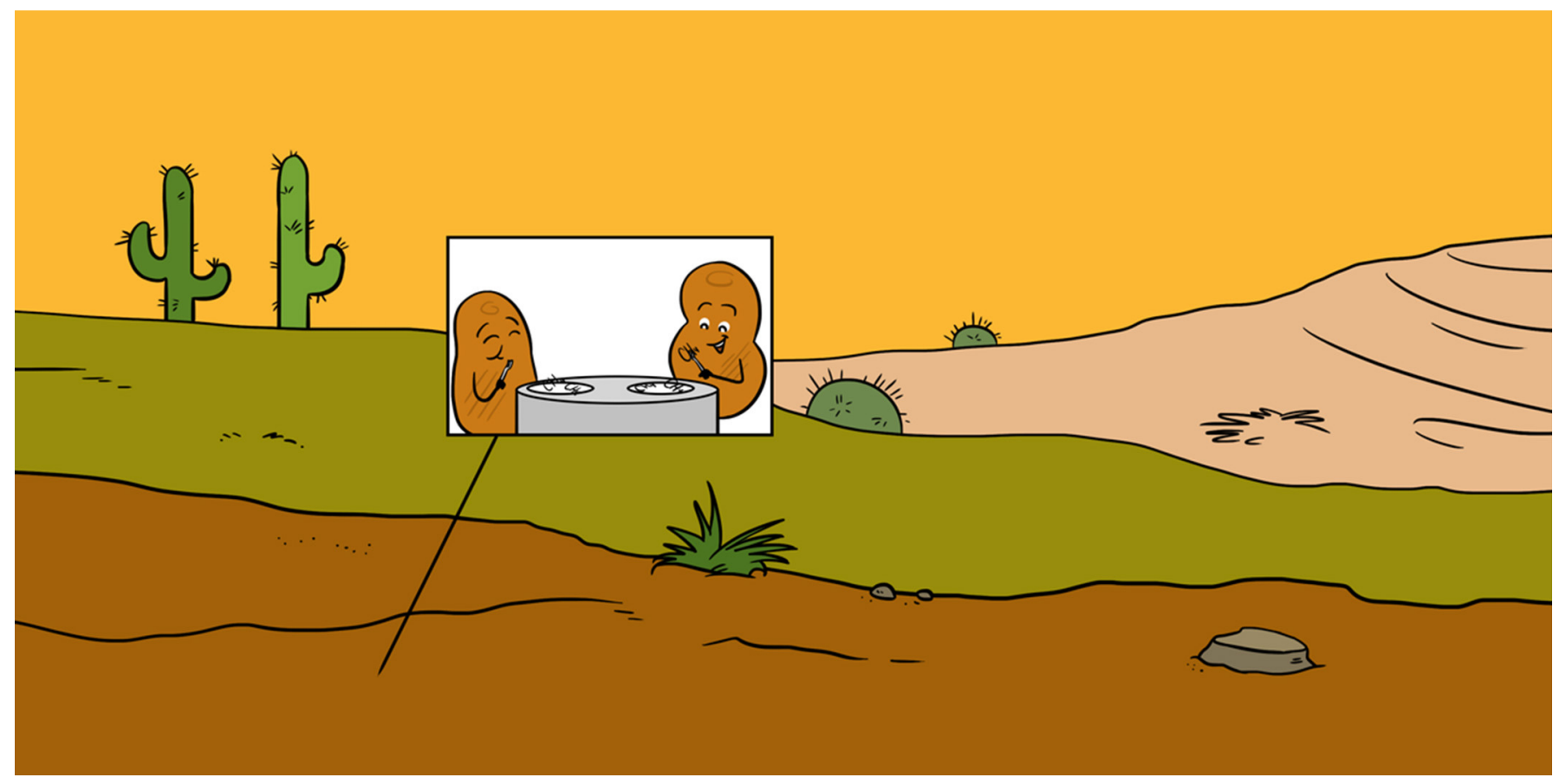

\title{
CAN METHANE-EATING BACTERIA IN DRYLANDS HELP US REDUCE GREENHOUSE GASES?
}

\section{Angela Lafuente ${ }^{1,2^{*}}$ and Concha Cano-Díaz ${ }^{1}$}

${ }^{1}$ Departamento de Biología y Geología, Física y Química Inorgánica, Escuela Superior de Ciencias Experimentales y Tecnología, Universidad Rey Juan Carlos, Móstoles, Spain

${ }^{2}$ College of Forest Resources and Environmental Science, Michigan Technological University, Houghton, MI, United States

\section{YOUNG REVIEWER:}

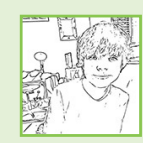

SEBASTIAN

AGE: 10
What is a dryland? The first thing that may come to your mind is a desert-like place where nothing can live or grow. Despite the scarcity of water, dryland ecosystems are diverse and will expand due to global climate change. The main cause of global warming is the increase of greenhouse gases in our atmosphere. To solve this, we obviously need to reduce the emission of greenhouse gases, but the study of microorganisms in nature also gives us exciting clues for how to address the problem of global warming. Microorganisms live in all possible Earth environments, and luckily some of them can even take greenhouse gases from the air as their food! In this article, we describe our search of the global soils for bacteria that can consume one of the most powerful greenhouse gases, methane $\left(\mathrm{CH}_{4}\right)$. Contrary to what was expected, we found that these bacteria live in drylands all over the world! 
Figure 1

Methods that we follow to find and study soil methanotrophs. We selected drylands all around the world and took soil samples (1).

We analyzed the properties of those soils, such as organic matter content and $\mathrm{pH}$ (2). We extracted the genetic information (DNA) of the bacteria present in the soil (3). Studying the DNA, we obtained information about the abundance, richness, and community structure of the methanotrophs from each soil sample $(\mathbf{4 , 5})$. Then we used mathematics to figure out which are the most relevant soil or climate conditions for methanotrophs (6).

\section{ABIOTIC}

Non-living abiotic factors in an environment include temperature, water, and light.

\section{ARIDITY}

Mathematical relationship between the amount of precipitation (rain, fog, or snow) and the evaporation of water. It describes how deficient water is in an ecosystem.

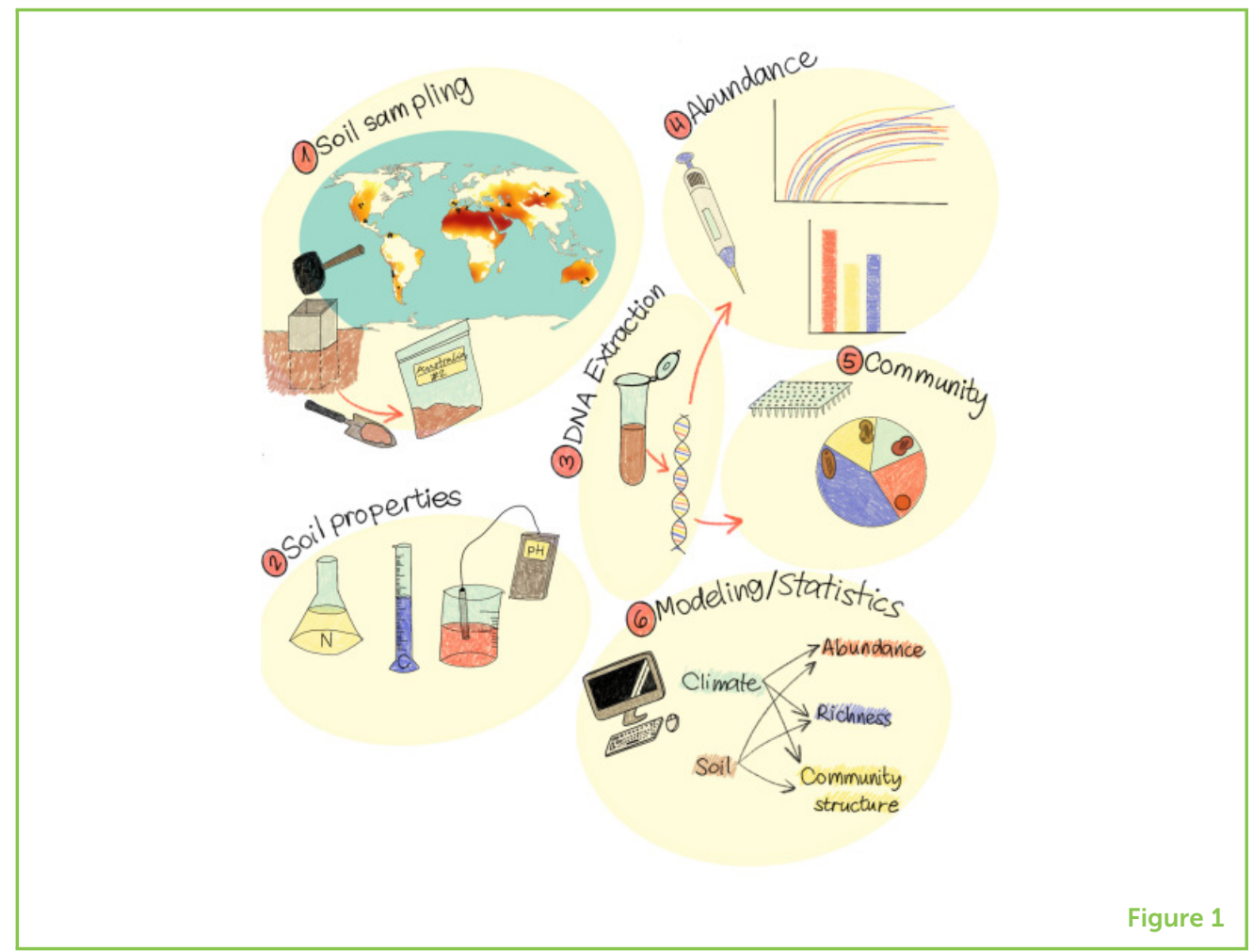

\section{THE LARGEST TERRESTRIAL ECOSYSTEM ON EARTH: DRYLANDS}

Drylands are characterized by scarce rainfalls and consequently do not have lush vegetation. However, drylands cover a whole range of different ecosystems, from the driest place on Earth, the hot desert of Atacama in Chile, to the leafy eucalyptus forests in Australia where Koalas live (Figure 1.1). Dryland ecosystems also contain huge numbers of organisms, many of which are plants and animals that live only in drylands and have adapted to the harsh conditions. Drylands are the biggest terrestrial ecosystem, occupying almost half of the Earth's land surface (45\%) and are home to more than $40 \%$ of the human population. So, you can see why drylands are extremely important areas of the earth to research.

Living beings and non-living substances in the environment, like plants and water, are intimately connected in by cycles in nature. These non-living substances are called abiotic factors. Water is crucial for all processes that are related to life, from plant growth to the development of communities of soil microorganisms. Therefore, water is the most important abiotic factor in an ecosystem. We measure the availability of water in an ecosystem with a measurement called aridity, a mathematical relationship between the amount of precipitation (rain, fog, or snow) and the evaporation of water. The less available water there, the more arid a place is (Figure 1.1). 
ABUNDANCE

The number of individuals of a certain type present in an environment.

\section{METHANOGENS}

Group of

microorganisms that do not need oxygen to survive and therefore can live in oxygen-free environments. They produce methane while decomposing organic matter, such as leaves or wood fragments.

\section{METHANOTROPHS}

\section{Group of} microorganisms that are capable of using up methane as their source of carbon and energy. They are methane eaters.

In drylands, where water is not always available, the natural cycles between living beings and non-living substances are hugely affected. When there is no water from rain and the humidity goes down, this affects the carbon $(\mathrm{C})$ and nitrogen $(\mathrm{N})$ cycles, reducing the abundance of these elements in soil, which impacts plants, animals, and microorganisms. All this makes drylands extremely vulnerable to ongoing climate change.

\section{SOIL BACTERIA AND METHANE}

The Earth is surrounded by a gaseous layer called the atmosphere, which protects us form solar radiation and helps maintain the overall temperature of the Earth. The principal components of the atmosphere are nitrogen (78\%) and oxygen (21\%), but there are many other gases in the atmosphere as well. Some atmospheric gases, such as carbon dioxide $\left(\mathrm{CO}_{2}\right)$ and water vapor, are the greenhouse gases, so called because they trap the Sun's heat, working like the glass in a greenhouse. The greenhouse gases let the Sun's light reach the Earth's surface but prevent heat from leaving the atmosphere. This trapping of heat contributes to global warming.

The most abundant human-produced greenhouse gas in the atmosphere is $\mathrm{CO}_{2}$, released from burning fossil fuels. However, the second most important gas contributing to global warming is methane $\left(\mathrm{CH}_{4}\right)$. Methane is a simple molecule formed by one atom of carbon $(\mathrm{C})$ and four atoms of hydrogen $(\mathrm{H})$. The warming effect of one molecule of methane is equivalent to 25 molecules of $\mathrm{CO}_{2}$, making it a super-powerful greenhouse gas. Methane is produced by methanogens, a group of microorganisms that do not need oxygen to survive and therefore can live in oxygen-free environments like rice fields, lake sediments, and wetlands. Methanogens also live in the digestive tracts of animals, such as the stomachs of cattle and even in humans! Methanogens are responsible for animal burps and farts! Methanogens also produce methane while decomposing organic matter, such as leaves or wood fragments. In addition to agriculture, other human activities, such as the oil and gas industries also release large amounts of methane into our atmosphere [1] (Figure 2).

The methane released into the atmosphere is greatly contributing to climate change and there is only one group of organisms that can consume it, the methanotrophs. This group of microorganisms is capable of using up methane as their source of carbon and energy. These microorganisms basically eat methane (Figure 2)! In drylands, methane production is low because of the scarcity of water (remember, methanogens typically live in flooded soils and other oxygen-free environments). However, due to the large extent of drylands and the global increase of methane in the atmosphere, dryland ecosystems could be of great interest if methanotrophs are also present and abundant there. 


\section{Figure 2}

Main methane $\left(\mathrm{CH}_{4}\right)$ sources and sinks.

\section{DNA EXTRACTION}

Laboratory procedure in which cells are broken open to release the genetic material (DNA) they contain inside, without damaging the DNA.

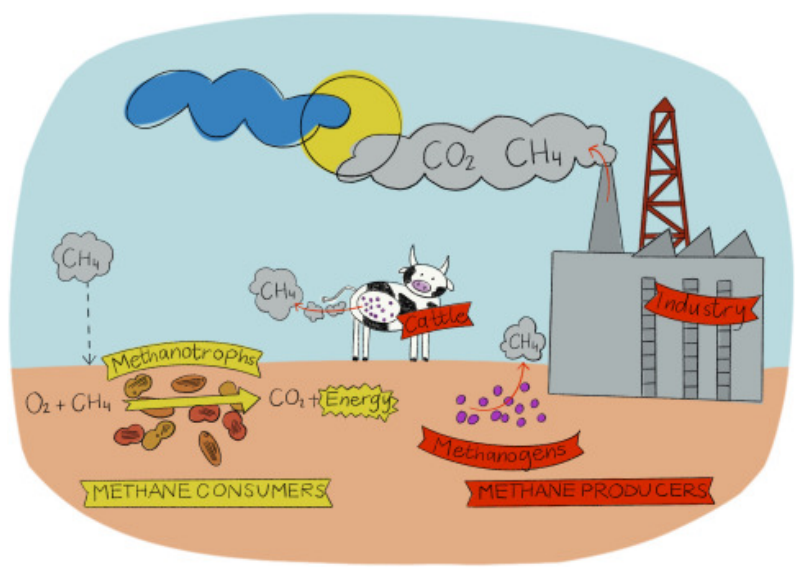

Figure 2

\section{HOW TO FIND AND STUDY METHANOTROPHS}

In our research, we were interested in learning if methanotrophs are common in the soils of drylands worldwide, and if they are sensitive to climate conditions and soil properties, like most soil microorganisms. First, we selected 80 dryland sites all around the world (Figure 1.1). At each site, we collected climate information, such as mean annual temperature, annual precipitation, and aridity. We also took soil samples and analyzed properties, such as the amount of organic matter (Organic Carbon), pH, and sand content (Figure 1.2). High soil organic matter indicates the soil is fertile, meaning it has the nutrients that plants, soil animals and microorganisms need to grow. $\mathrm{pH}$ analysis tells us how acidic the soil is. $\mathrm{pH}$ is one of the most important factors regulating soil bacteria growth. For example, when soils are very acidic like vinegar, only specific acid-tolerant bacteria can live there. Soil grains are very close to each other but also leave spaces for air and water to enter. The amount of sand, the largest type of particle in the soil, tells us how big these soil spaces are. This way, a high sand content means there are big spaces, so that air can enter the soils easily, but water and nutrients can also drain easily.

To study the methanotrophs in our soil samples, we need the genetic information (DNA) of these bacteria [2]. First, we obtain all the DNA present in our soil samples, through a process called DNA extraction (Figure 1.3). This process is done in the laboratory using powerful enzymes that break the cells open without damaging the genetic information. We then analyse the extracted DNA for a specific region that is present only in methanotrophs. This stretch of DNA is a gene called $p m o A$. The $p m o A$ gene contains the instructions for the protein that allows methanotrophs to eat atmospheric methane. Knowing the concentration of the $p m o A$ gene in each soil sample tells us how many methanotrophs were living in that sample (Figure 1.4). There are several closely related species of methanotrophs that all have similar 
Figure 3

Microbial communities can be described using three properties. Abundance is the total number of bacteria of a certain type present. Richness is the number of different kinds of bacteria present in an environment. Community structure describes how many different kinds of bacteria there are and how abundant each kind is.

\section{RICHNESS}

The number of species (different kinds) of organisms present in an environment.

\section{COMMUNITY}

STRUCTURE

The combined richness and abundance in the community.

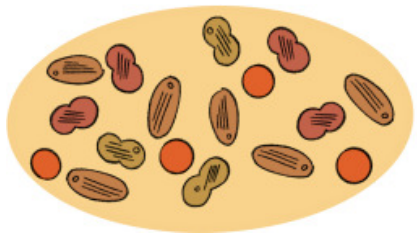

Abundance: 17 bacteria

Richness: 4 species

Community structure

$6 \bigcirc 4030$

Figure 3

DNA information, but different species have tiny genetic differences in their DNA, so we can use DNA to identify different methanotrophs, like a fingerprint (Figure 1.5).

Our DNA studies help us to obtain information about the abundance (total number of bacteria of a certain type present), richness (the number of different kinds of bacteria present), and community structure (the different kinds of bacteria and the abundance of each kind) of the methanotrophs from each soil sample (Figure 3). Then, we use mathematics to figure out which soil or climate conditions are the most important for methanotrophs (Figure 1.6).

\section{WHERE THE METHANOTROPHS LIVE}

We were not sure if we would find methanotrophs in drylands, since these microorganisms need methane to live and drylands are not the typical ecosystem for methane production. So, finding methanotrophs in all our dryland soil samples was an extraordinary finding! We can now say that methanotrophs are widely distributed in global drylands. Surprisingly, we even found some methanotrophs that are usually found in humid places, such as Denmark, Scotland, or New Zealand.

We also found that, in drylands, the average annual temperature and aridity are not the main conditions influencing the abundance and richness of methanotrophs. Abundance and richness may be driven by other factors, such as rainfall. However, climate conditions like mean annual temperature, rainfall, aridity, and soil properties, such as organic matter, $\mathrm{pH}$, and sand content did affect the community structure of methanotrophs. For example, higher temperatures increased the abundance of certain methanotrophs that are heat-resistant. In other words, those drylands with higher temperatures, the methanotroph communities may contain more heat-resistant methanotrophs. Climate conditions can also affect soil properties, for example by favoring the breakdown of rocks, which increases sand content, or by modifying soil $\mathrm{pH}$ and organic matter. These soil properties affect the amount of air that can get into the soil, which we found to be very important for the community structure of the methanotrophs. 


\section{WHAT WE LEARNT FROM METHANOTROPHS IN DRYLANDS?}

As we found, methanotrophs are abundant and widely distributed in drylands worldwide. Both climate and soil affect the communities of methanotrophs. Moreover, we found the community structure of methane eating bacteria was highly dependent on climate conditions, such as amount of rainfall and temperature, and soil characteristics as soil organic content.

Because we found that climate influences the methanotrophs, we expect that ongoing climate change will modify methanotroph communities in the coming years, affecting the consumption of atmospheric methane. To date we knew methanotrophs lived on cold and humid places, which will be surely affected by climate change. The vast amount of land that drylands cover and the many methanotrophs they contain may make these areas extremely important for consuming atmospheric methane in the future. In other words, dryland bacteria can help us reduce greenhouse gases! Taking good care of drylands now and continue studying the hidden marvels they contain is important to deal with our future warmer planet. Methane-Eating Bacteria in Drylands can help us!

\section{ORIGINAL SOURCE ARTICLE}

Lafuente, A., Bowker, M. A., Delgado-Baquerizo, M., Durán, J., Singh, B. K., and Maestre, F. T. 2019. Global drivers of methane oxidation and denitrifying gene distribution in drylands. Glob. Ecol. Biogeogr. 28:1230-43. doi: 10.1111/geb.12928

\section{REFERENCES}

1. Cadena, S., Cervantes, F., Falcón, L., and García-Maldonado, J. 2019. The role of microorganisms in the methane cycle. Front. Young Minds 7:133. doi: 10.3389/frym.2019.00133

2. Schallenberg, L., Wood, S., Pochon, X., and Pearman, J. 2020. What can DNA in the environment tell us about an ecosystem? Front. Young Minds 8:150. doi: 10.3389/frym.2019.00150

SUBMITTED: 27 April 2020; ACCEPTED: 20 May 2021;

PUBLISHED ONLINE: 16 June 2021.

EDITED BY: Rémy Beugnon, German Centre for Integrative Biodiversity Research (iDiv), Germany

CITATION: Lafuente A and Cano-Díaz C (2021) Can Methane-Eating Bacteria in Drylands Help Us Reduce Greenhouse Gases? Front. Young Minds 9:556361. doi: $10.3389 /$ frym.2021.556361 


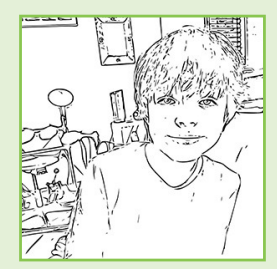

CONFLICT OF INTEREST: The authors declare that the research was conducted in the absence of any commercial or financial relationships that could be construed as a potential conflict of interest.

COPYRIGHT @ 2021 Lafuente and Cano-Díaz. This is an open-access article distributed under the terms of the Creative Commons Attribution License (CC BY). The use, distribution or reproduction in other forums is permitted, provided the original author(s) and the copyright owner(s) are credited and that the original publication in this journal is cited, in accordance with accepted academic practice. No use, distribution or reproduction is permitted which does not comply with these terms.

\section{YOUNG REVIEWER}

\section{SEBASTIAN, AGE: 10}

I like sports, reading, math, and animals.

\section{AUTHORS}

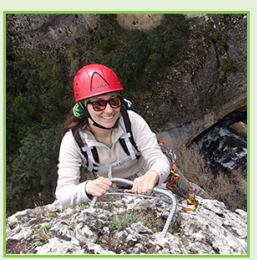

\section{ANGELA LAFUENTE}

I am currently a post-doc at Michigan Technological University, working on carbon cycling in tropical peatlands. I am an ecologist interested in understanding how global change affects soil microorganisms and greenhouse gas fluxes. In my free time, I enjoy the nature going on a hike, cycling, or skiing. *ellyon.diebrunnen@gmail.com

\section{CONCHA CANO-DÍAZ}

I am a biologist finishing my Ph.D. at Universidad Rey Juan Carlos (Spain). My research is focused on the distribution and ecological preferences of soil cyanobacteria. I am currently studying the effects of climate change and soil formation processes on cyanobacterial communities around the world. I love to make scientific illustrations and in my free time I enjoy playing music with the ukulele and singing in the choir. 